\title{
Imported cutaneous leishmaniasis: a 13-year experience of a Polish tertiary center
}

\author{
Anna Kuna ${ }^{1}$, Michał Gajewski², Martyna Bykowska ${ }^{1,3}$, Halina Pietkiewicz ${ }^{3}$, Romuald Olszański ${ }^{4}$, Przemysław Myjak ${ }^{3}$ \\ ${ }^{1}$ Department of Tropical and Parasitic Diseases, Institute of Maritime and Tropical Medicine in Gdynia, Faculty of Health Sciences, \\ Medical University of Gdansk, Gdansk, Poland \\ ${ }^{2}$ Department of Infectious Diseases, Faculty of Medicine, Medical University of Gdansk, Gdansk, Poland \\ ${ }^{3}$ Department of Tropical Parasitology, Institute of Maritime and Tropical Medicine in Gdynia, Faculty of Health Sciences, \\ Medical University of Gdansk, Gdansk, Poland \\ ${ }^{4}$ Department of Maritime and Hyperbaric Medicine in Gdynia, Military Institute of Medicine in Warsaw, Poland \\ Adv Dermatol Allergol 2019; XXXVI (1): 104-111 \\ DOI: https://doi.org/10.5114/ada.2019.82830
}

\begin{abstract}
Introduction: Leishmaniasis is a vector-borne infection endemic in 98 countries. Its cutaneous form (CL) causes skin lesions on exposed parts of the body and may lead to scarring. The numbers of imported cases of $\mathrm{CL}$ are increasing in Europe but the incidence of $C L$ importation in Poland is unknown.

Material and methods: A list of all patients diagnosed with CL at the Department in the years 2005-2017 was obtained. The study presents their data including age, sex, areas visited, purpose of travel, time from the onset of symptoms to correct diagnosis, appearance of lesions, results of impression smears and PCR, and superinfection, if detected, as well as treatment methods and their outcomes.

Results: Altogether, 14 cases of cutaneous leishmaniasis were identified. The study demonstrates an increase in the number of cases of imported CL at our center over the last 5 years. The time to correct diagnosis was long in spite of the fact that the lesions had usually an appearance typical of CL.

Conclusions: Intensified education of physicians and travelers, as well as improvement in the access to travel medicine services and to the diagnosis and treatment methods appropriate for CL, are needed in our country. In our opinion, surveillance of leishmaniasis should be introduced in Poland.
\end{abstract}

Key words: cutaneous leishmaniasis, neglected diseases, imported communicable diseases, emerging communicable diseases, travel-related illness, disease vectors.

\section{Introduction}

Leishmaniasis is an euglenozoan parasitic vectorborne infection endemic in 98 countries, with over 350 million people at risk globally [1]. The disease occurs in three main forms: (a) visceral leishmaniasis (VL), or kalaazar, the most severe form, fatal in $95 \%$ of untreated cases, characterized by recurring fever, wasting, anemia, and hepatosplenomegaly; (b) cutaneous leishmaniasis (CL) which causes skin lesions such as ulcers on exposed parts of the body and may lead to scarring; and (c) mucocutaneous leishmaniasis (MCL), or espundia, a form involving the mucous membranes of the nose, mouth and throat and leading to facial disfigurement [2].
Leishmania can be divided into Old World and New World species. Old World CL acquired in Africa, Asia, the Middle East, and Mediterranean/Southern Europe is transmitted by sandflies of the genus Phlebotomus. Major causative species include Leishmania major, L. tropica, L. infantum, L. donovani, and L. aethiopica. Old World CL is usually a benign cutaneous disease without spread to mucosal sites. L. infantum and L. donovani also cause visceral leishmaniasis, but it is seldom concomitant with the cutaneous form. New World cutaneous leishmaniasis is endemic throughout Latin America, ranging from Mexico to Argentina; it is transmitted by sandflies of the Lutzomyia genus. The disease caused by the members of the Vianna subgenus including Leishmania (Viannia) braziliensis, L. (V.) guyanensis, L. (V.) panamensis, and

Address for correspondence: Michał Gajewski MD, Department of Infectious Diseases, Faculty of Medicine, Medical University of Gdansk, 18 Mariana Smoluchowskiego St, 80-214 Gdansk, Poland, e-mail: mich.gajewski@gmail.com Received: 12.05.2018, accepted: 30.06.2018. 
L. (V.) peruviana may be locally aggressive and can progress to the destructive mucocutaneous infection. The species of the Leishmania subgenus present in the New World include L. mexicana, L. amazonensis, L. venezuelensis, and L. infantum (= L. chagasi); the disease caused by them almost never involves the naso- or oropharyngeal mucosa [1, 3]). Recently, some novel species causing the disease in humans have been identified both in the Old and the New World [4]. Cutaneous leishmaniasis is transmitted either in the anthroponotic (primarily L. tropica and L. donovani) or zoonotic cycle (all other species). Non-vector transmission (e.g. by accidental laboratory infection or intravenous drug use) is rare [3].

The disease is present mainly (but not exclusively) in the tropical and neotropical low-income countries, with malnutrition, population displacement, poor housing, impaired immunity and poverty constituting the most important factors facilitating its spread [2, 3]. Although the burden of $C L$ is in some countries high $[5,6]$ and the disease often has serious long-lasting psychosocial consequences [7], it is rarely fatal, which is why the World Health Organization (WHO) has declared it one of the 17 neglected tropical diseases [2].

Although it has been estimated that 1.5-2 million new cases of CL occur every year [8], the real global incidence of $C L$ is probably higher because of asymptomatic or misdiagnosed cases [3,9]. The trends in numbers of new cases of $C L$ vary depending on location: the numbers are increasing significantly in the high-burden countries of the WHO Eastern Mediterranean Region but they are stable in the high-burden countries elsewhere $[2,6]$. The numbers of imported cases of cutaneous leishmaniasis are also increasing according to reports from other nonendemic European countries, making CL the most common clinical form of imported leishmaniasis [10].

Poland has been a country with no autochthonous cases of leishmaniasis detected [10]. The disease is not notifiable according to the national law [11], and the incidence of $C L$ importation is unknown, similar to many other non-endemic countries [10].

\section{Aim}

The aim of this study was to investigate and present the clinical features, diagnosis, treatment and outcomes of the cases of CL treated at the University Center for Maritime and Tropical Medicine, Gdynia, Medical University of Gdansk, one of the two tertiary reference centers for tropical medicine in Poland, in the years 2005-2017.

\section{Material and methods}

A list of all patients diagnosed with cutaneous leishmaniasis at the Department of Tropical and Parasitic Diseases, University Center for Maritime and Tropical Medicine, Gdynia, Medical University of Gdansk, was ob- tained by an automated query in the electronic database of patients' medical files.

All patients, in whom CL was suspected, were clinically evaluated and Giemsa-stained impression smears from the ulcerative lesion or from fresh tissue bioptates were examined for the presence of the amastigotes. Polymerase chain reaction (PCR) was also used to detect the DNA of Leishmania spp. in tissue bioptates from 2009 onwards, as described in our earlier studies [12, 13].

The study was conducted in accord with the Declaration of Helsinki and approved by the Independent Ethics Committee of the Medical University of Gdansk. For this type of the study, no formal consent is required.

\section{Results}

Altogether, 14 cases of cutaneous leishmaniasis were identified among the patients treated at the Department in the years 2005-2017. Their demographic and clinical data are summarized in chronologic order in Table 1, including age, sex, areas visited, purpose of travel, time from onset of symptoms to correct diagnosis, appearance of lesions, results of impression smears and PCR, and superinfection if detected.

\section{General characteristics of the studied group}

The majority of patients $(n=13 ; 93 \%)$ were male. The median age was 28.5 years (23-61 years). None of the patients was known to have any immunosuppression. The number of cases per year is presented in Figure 1.

\section{Probable geographic origin of the infection and the purpose of travel}

The patients travelled mainly to Central or South America $(n=7 ; 50 \%)$, Central or South East Asia $(n=4$; $28.6 \%)$ and Africa $(n=3 ; 21.5 \%)$. The purpose of travel was mainly tourism ( $n=10 ; 71.4 \%$ ), followed by professional activities ( $n=2 ; 14.3 \%)$ and military service $(n=2 ; 14.3 \%)$.

\section{Clinical picture}

The majority of cases presented themselves as a classical single ulceration ( $n=7 ; 50 \%)$; in further 4 (28.6\%) cases, the ulcers were multiple. Three (21.4\%) cases had an unusual appearance: blisters with erythematous background $(n=1)$, hard exudative lesions with subsequent papular dissemination $(n=1)$, and papular lesions $(n=1)$. The eruptions were located mainly on limbs ( $n=8 ; 57 \%)$, but also on the face and limbs $(n=1)$, trunk and limbs $(n=3 ; 21.5 \%)$ and the trunk only $(n=2 ; 14.3 \%)$.

\section{Time from the onset of symptoms to correct diagnosis}

The time from the onset of symptoms to correct diagnosis was known in $11(78.6 \%)$ cases. It was up to 1 month in $3(21.4 \%)$ cases, 2 or 3 months in 2 (14.3\%) cases, 
Table 1. Demographic and clinical data of the studied group, in chronological order

\begin{tabular}{|c|c|c|c|c|c|c|c|c|c|c|}
\hline 䓂 & $\underset{\leftarrow}{\stackrel{\alpha}{<}}$ & $\stackrel{\times}{\sim}$ & $\begin{array}{c}\text { Travel } \\
\text { destination }\end{array}$ & $\begin{array}{l}\text { Purpose } \\
\text { of travel }\end{array}$ & Appearance of lesions & $\begin{array}{l}\text { Time from } \\
\text { onset to } \\
\text { diagnosis }\end{array}$ & $\begin{array}{l}\text { Microscopic } \\
\text { examination }\end{array}$ & PCR & Species & $\begin{array}{l}\text { Superin- } \\
\text { fection }\end{array}$ \\
\hline 1 & 30 & M & Nepal & Tourism & $\begin{array}{c}\text { Blisters with } \\
\text { erythematous } \\
\text { background on the face } \\
\text { and limbs }\end{array}$ & Unknown & Positive & $\begin{array}{c}\text { Not } \\
\text { performed }\end{array}$ & Unknown & $\begin{array}{l}\text { S. pyogenes } \\
\text { S. aureus } \\
\text { MSSA }\end{array}$ \\
\hline 2 & 26 & M & Belize & Military & $\begin{array}{l}\text { Inflammatory infiltration } \\
\text { and ulcerations of the } \\
\text { fifth finger and wrist of } \\
\text { the left hand }\end{array}$ & 4 months & Positive & $\begin{array}{c}\text { Not } \\
\text { performed }\end{array}$ & Unknown & None \\
\hline 3 & 61 & M & Madagascar & Tourism & $\begin{array}{l}\text { Ulcerations of upper and } \\
\text { lower limbs }\end{array}$ & 1 month & Negative & $\begin{array}{c}\text { Not } \\
\text { performed }\end{array}$ & Unknown & S. pyogenes \\
\hline 4 & 49 & M & $\begin{array}{l}\text { Burkina } \\
\text { Faso }\end{array}$ & Professional & $\begin{array}{l}\text { Ulceration of the } \\
\text { umbilical area with small } \\
\text { satellite nodules }\end{array}$ & 5 months & Positive & Positive & L. major & None \\
\hline 5 & 26 & M & Chad & Military & $\begin{array}{l}\text { Ulceration of the left } \\
\text { hand }\end{array}$ & 1 month & Negative & Positive & L. major & None \\
\hline 6 & 60 & M & $\begin{array}{l}\text { Turkme- } \\
\text { nistan }\end{array}$ & Professional & Upper left limb ulceration & $\begin{array}{l}\text { Several } \\
\text { months }\end{array}$ & Positive & Positive & L. major & $\begin{array}{c}\text { S. } \\
\text { haemolyticus } \\
\text { S. } \\
\text { marcescens }\end{array}$ \\
\hline 7 & 27 & $\mathrm{~F}$ & Cuba & Tourism & $\begin{array}{l}\text { Hard, exudative lesions } \\
\text { on the crus, finger, later } \\
\text { disseminated papules }\end{array}$ & 5 months & Negative & Positive & Unknown & None \\
\hline 8 & 27 & M & $\begin{array}{l}\text { French } \\
\text { Guyana }\end{array}$ & Tourism & $\begin{array}{l}\text { Round erythematous foci } \\
\text { on the trunk and upper } \\
\text { limbs }\end{array}$ & Unknown & Positive & Positive & Unknown & Fungal \\
\hline 9 & 23 & M & $\begin{array}{l}\text { Malaysia, } \\
\text { Indonesia, } \\
\text { Myanmar, } \\
\text { Thailand, } \\
\text { Singapore, } \\
\text { Turkey, Iran }\end{array}$ & Tourism & Right crus ulceration & 4 months & Negative & Positive & Unknown & None \\
\hline 10 & 30 & $M$ & $\begin{array}{l}\text { Thailand, } \\
\text { Myanmar, } \\
\text { Southern } \\
\text { France }\end{array}$ & Tourism & $\begin{array}{l}\text { Ulceration of the left } \\
\text { axilla }\end{array}$ & $\begin{array}{l}\text { Several } \\
\text { months }\end{array}$ & Positive & $\begin{array}{c}\text { Not } \\
\text { performed }\end{array}$ & Unknown & None \\
\hline 11 & 27 & $M$ & Bolivia & Tourism & $\begin{array}{l}\text { Papular lesions on the } \\
\text { trunk and limbs }\end{array}$ & 2 months & Negative & Positive & Unknown & None \\
\hline 12 & 29 & $M$ & Bolivia & Tourism & $\begin{array}{l}\text { Ulcerations of the } \\
\text { dorsum and the second } \\
\text { toe of the right foot }\end{array}$ & Unknown & Negative & Positive & Unknown & None \\
\hline 13 & 28 & $M$ & Peru & Tourism & $\begin{array}{l}\text { Ulceration of the left } \\
\text { forearm }\end{array}$ & 0 months* & Positive & Positive & Unknown & None \\
\hline 14 & 25 & $M$ & Bolivia & Tourism & $\begin{array}{l}\text { Ulceration of the right } \\
\text { lower limb (Fig. 2) }\end{array}$ & 3 months & Negative & Positive & Unknown & None \\
\hline
\end{tabular}

\footnotetext{
*The patient was diagnosed already during the travel but he refused the offered parenteral treatment with Sb due to his imminent return to Poland.
} 
4 months in 2 (14.3\%) cases and 5 or 'several' months in $3(21.4 \%)$ cases.

\section{Establishment of the diagnosis of leishmaniasis}

The diagnosis was confirmed by the PCR alone in $6(42.7 \%)$ cases, by the Giemsa stain alone in 4 (28.6\%) cases and by both the PCR and Giemsa stain in 3 (21.5\%) cases. In 1 case, the Giemsa stain was negative and the PCR was not yet available at the institution at that time, and therefore, the diagnosis was established solely based on the clinical picture and the response to treatment. The causative species was identified with gene sequencing as L. major in 3 (21.5\%) cases, but the identification was not performed in the remaining 11 patients because of lack or failure of equipment at the time of diagnosis.

\section{Treatment and outcomes}

The majority of the patients $(n=10 ; 71.5 \%)$ were treated systemically: 7 (50\%) patients with pentavalent antimonials, 2 (14.3\%) with ketoconazole and 1 (7.1\%) with miltefosine and ketoconazole. Among this group, 7 (50\%) patients additionally received allopurinol, 1 patient underwent a prior surgical excision which resulted in the diagnosis, and 1 patient was treated with hyperbaric oxygen. Three (21.4\%) patients were treated with local treatment alone: 2 (14.3\%) with cryotherapy and wound care, and 1 case with simple wound care alone because of the shortage of pentavalent antimonials at that time. One patient was treated with cryotherapy and

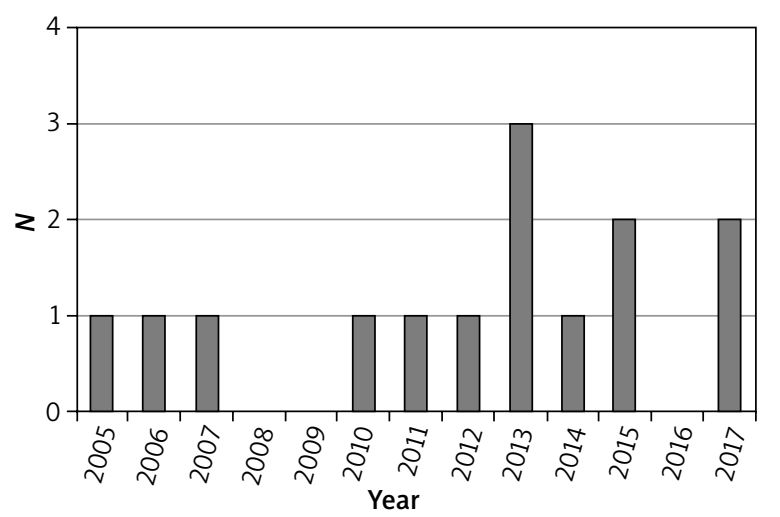

Figure 1. Number of patients with CL treated per year at the institution

systemic allopurinol. The response was good in the majority of cases ( $n=12 ; 85.7 \%$ ), while it was unsatisfactory in $1(7.1 \%)$ case. The ultimate outcome was unknown in $1(7.1 \%)$ case. Summary of the treatment methods applied and the achieved outcomes is presented in Table 2.

\section{Discussion}

Leishmaniasis is not a notifiable disease in Poland despite the WHO recommendations $[6,10]$ and the suggestions of the European Centre for Diseases Prevention and Control experts [14], and therefore, the overall national

Table 2. Treatment and outcomes in the studied group

\begin{tabular}{|c|c|c|}
\hline Patient & Treatment & Outcome \\
\hline 1 & Ketoconazole, antibiotics, wound care & Good \\
\hline 2 & Sodium stibogluconate (systemic), ketoconazole, allopurinol, antibiotics, wound care & Good \\
\hline 3 & Ketoconazole, allopurinol, antibiotics, wound care & Good \\
\hline 4 & Sodium stibogluconate (systemic), ketoconazole, wound care & Good \\
\hline 5 & Meglumine antimoniate (systemic), ketoconazole, allopurinol & Good \\
\hline 6 & $\begin{array}{c}\text { Meglumine antimoniate (systemic), ketoconazole, allopurinol, antibiotics, wound care, } \\
\text { hyperbaric oxygen }\end{array}$ & Good \\
\hline 7 & Meglumine antimoniate (systemic), ketoconazole, allopurinol & No response, lost to follow-up \\
\hline 8 & Meglumine antimoniate (systemic), ketoconazole, allopurinol & Good \\
\hline 9 & Wound care & Lost to follow-up \\
\hline 10 & Surgical excision, meglumine antimoniate (systemic) & Good \\
\hline 11 & Cryotherapy, wound care & Good \\
\hline 12 & Cryotherapy, wound care & Good \\
\hline 13 & Allopurinol, cryotherapy, wound care & Good \\
\hline 14 & Miltefosine, allopurinol, ketoconazole & Good \\
\hline
\end{tabular}




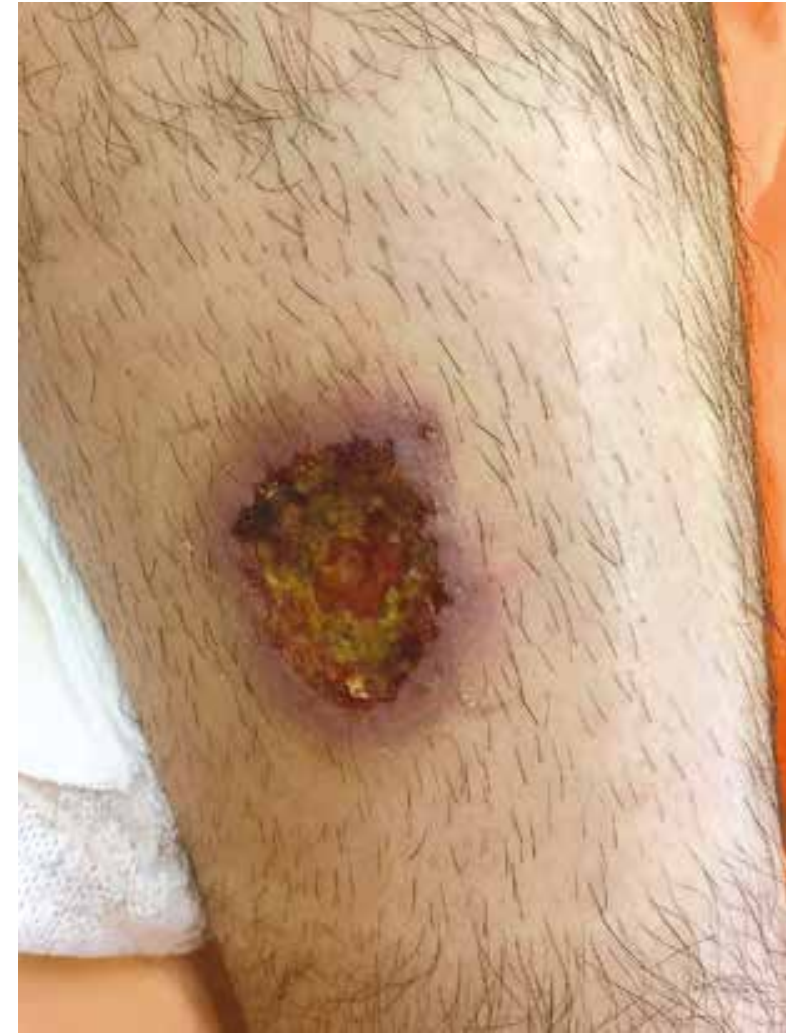

Figure 2. Ulceration of the right lower limb typical of $C L$ in a 25 -year-old male tourist who returned from Bolivia

incidence of the disease is unknown. Only few earlier case-reports of human CL at our center [15] or at other Polish centers [16-30] have ever been published. Thus, it may cautiously be assumed to our best knowledge that this series of 14 cases constitutes the great majority of $\mathrm{CL}$ cases diagnosed and treated in Poland in the recent 13 years.

The lack of epidemiological surveillance of leishmaniasis in Poland is disturbing, considering the recent influx of immigrants from CL-endemic high-burden countries such as Syria into the European Union [31-33], as well as the continuous expansion of the range of phlebotomine sandflies northwards in Europe as they are already established in Austria, Germany and Hungary - countries located along with Poland in Central Europe [34, 35].

The analyzed population, although small, is similar in sex and age to the other ones studied in Europe. The study also demonstrates a significant increase in the number of cases of imported CL, mainly in tourists, treated per year at our center over the last 5 years (Figure 1), which is consistent with the reports from the United Kingdom, the Netherlands and Austria [36-40]. Poland is one of the top performers in Europe in terms of outbound tourism growth (+7\% annually) [41], nevertheless, very little is known about the non-European destinations trending among Poles [42, 43]. Four (28.6\%) patients were infected during work or military service abroad, which confirms the importance of $C L$ as an occupational disease [44]. On the other hand, not a single case was diagnosed in immigrants or in people visiting friends or relatives (VFRs), which stands in contrast to countries such as Germany or Australia, where immigrants constitute a significant share in the total incidence of $\mathrm{CL}$ importation [33, 45].

Our earlier study demonstrated that the awareness of malaria and of the prophylaxis methods against it remains unsatisfactory among Polish travelers, and that some of them, especially those committed to 'ecologic' or 'natural' lifestyle, despise the prophylaxis methods as unnecessary or even noxious [46]; it may possibly be even more accurate in regard to the relatively lesser known leishmaniasis. The absence of any reimbursement by the national health insurance in Poland for the travel medicine services and for travel-related vaccinations or prophylactic drugs (with the exception of some antibiotics) further deters travelers, often young students interested in low-cost tourism, from seeking them.

Half of the patients at our institution were infected in the New World, which is similar to the British study [36] and significantly more than in the Dutch study [37]; this is probably due to the fact that the majority of our patients travelled for tourism, whereas roughly half of the patients in the Dutch series were military personnel (compared to $14.3 \%$ in our study and to $17 \%$ in the British study), and the majority of them served in Afghanistan $[37,47]$. In the recent two decades, Polish military personnel have also served in high numbers in the Middle Eastern and Asian countries endemic for CL (Iraq, Afghanistan); however, in contrast to the British, the Dutch or the American servicemen deployed to the region, none of their Polish counterparts was diagnosed with CL [48, 49], and the only 2 soldiers included in our study served elsewhere: one in Belize, the site of a jungle training facility where soldiers of other nations have also been known to contract the disease [50,51], and one in Chad on a peacekeeping mission. Such a discrepancy might raise doubts as to whether it was caused indeed by the lower rate of infection compared to soldiers of other nations serving in Iraq or Afghanistan or it was a result of underdiagnosing of Polish troops.

The time from the onset of symptoms to the correct diagnosis was relatively long in spite of the fact that the lesions among the vast majority of the analyzed patients had an appearance typical for CL (Figure 2); this reflects the problems highlighted in other studies, such as the popular misconception that leishmaniasis is a strictly tropical disease, in spite of the numerous cases acquired in Southern and South-Eastern Europe [52-65], the lack of awareness among clinicians (including dermatologists) in Poland, similar to other non-endemic-countries [37], as well as among travelers [66]. One could only speculate 
how many cases of the imported $\mathrm{CL}$ remain undiagnosed in Poland, particularly in cases with atypical appearance of lesions.

The microscopic examination of the Giemsa stain was the mainstay of diagnosis up to 2009 at our institution, and the PCR was also used in the patients from that year onwards. The introduction of the PCR at our institution dramatically improved, like elsewhere [67-69], the sensitivity of diagnosis because as many as 6 (42.8\%) of the presented cases had a positive PCR result for Leishmania spp. in spite of the negative Giemsa stain and, consequently, would have been prone to misdiagnosis in the situation of absence of the molecular test, especially in cases of atypical or longer-lasting lesions, as the sensitivity of the Giemsa stain paradoxically decreases with longer duration of the infection [1].

The percentage of patients in whom the causative species was identified was unsatisfactory in this study, considering the utmost importance of species determination for the choice of appropriate management, which has been emphasized in all the recent recommendations $[8,70,71]$. Unfortunately, the gene sequencer required for the species identification failed with time, and no new apparatus was obtained due to underfinancing of the laboratory. This reflects the broader problem in the healthcare system across Poland of inadequate financing of the laboratory services which tend to be targeted as one of the first by the austerity measures of the medical institutions; the expenses for laboratory diagnostics per capita are in Poland among the lowest in the European Union [72, 73].

The treatment methods used reflect partially the difficulties in obtaining appropriate medication to our institution at various times: numerous pivotal antileishmanial drugs (pentavalent antimonials, miltefosine, pentamidine, topical paromomycin or benzethonium chloride) neither are registered in Poland nor do they hold an European Union-wide approval, thus being available exclusively through a complicated official procedure of individual import authorization; moreover, a general shortage in pentavalent antimonials supply throughout the world has repeatedly occurred in the recent years. Of note, treatment of many cases in our study did not conform to the recommendations of the LeishMan European Working Group because the majority of the patients were treated before the recommendations were issued [70]. As the recommendations favor local management such as cryotherapy in many clinical situations, cooperation with an experienced dermatologist is crucial in the treatment process.

One of the more important shortcomings of this study is the inadequate follow-up, similar to other studies [8]. It is particularly true in regard to the patients infected in the New World, as people with the New World $\mathrm{CL}$ should be actively monitored by clinical appearance, including by performing a careful nasal and oropharyngeal examination periodically up to 1 year, or at least
2 years if at increased risk for mucosal involvement [ 40 , $71,74]$, and this kind of surveillance was not maintained for the patients at our institution.

\section{Conclusions}

We present the largest series of $C L$ cases diagnosed and treated in Poland. Our study suggests that much remains to be undertaken in our country in terms of educating physicians, travelers, as well as of improving the access to travel medicine services and to the diagnosis and treatment methods appropriate for CL. No epidemiological data for leishmaniasis exist for Poland because of lack of epidemiological surveillance for the disease in the country; in our opinion, this situation needs to be altered, taking into account the geographic expansion of sandflies in Europe, the increasing influx of immigrants into the European Union, as well as the increasing popularity of tourism among Poles.

\section{Conflict of interest}

The authors declare no conflict of interest.

\section{References}

1. Showler AJ, Boggild AK. Cutaneous leishmaniasis in travellers: a focus on epidemiology and treatment in 2015. Curr Infect Dis Rep 2015; 17: 489.

2. Integrating neglected tropical diseases into global health and development: fourth WHO report on neglected tropical diseases. Geneva: World Health Organization 2017.

3. Reithinger R, Dujardin JC, Louzir H, et al. Cutaneous leishmaniasis. Lancet Infect Dis 2007; 7: 581-96.

4. Cotton JA. The expanding world of human leishmaniasis. Trends Parasitol 2017; 33: 341-4.

5. Karimkhani C, Wanga V, Coffeng LE, et al. Global burden of cutaneous leishmaniasis: a cross-sectional analysis from the Global Burden of Disease Study 2013. Lancet Infect Dis 2016; 16: 584-91.

6. Global leishmaniasis update, 2006-2015: a turning point in leishmaniasis surveillance. Wkly Epidemiol Rec 2017; 92: 557-65.

7. Bailey F, Mondragon-Shem K, Hotez P, et al. A new perspective on cutaneous leishmaniasis - implications for global prevalence and burden of disease estimates. PLoS Negl Trop Dis 2017; 11: e0005739.

8. Hodiamont CJ, Kager PA, Bart A, et al. Species-directed therapy for leishmaniasis in returning travellers: a comprehensive guide. PLoS Negl Trop Dis 2014; 8: e2832.

9. Esteva L, Vargas C, Vargas de León C. The role of asymptomatics and dogs on leishmaniasis propagation. Math Biosci 2017; 293: 46-55.

10. Gradoni L, López-Vélez R, Mokni M. Manual on case management and surveillance of the leishmaniases in the WHO European Region. World Health Organization, Geneva 2017.

11. Act of December 5, 2008 on preventing and combatting infections and infectious diseases in humans. Appendix 1 (official consolidated text) (2018). 
12. Myjak P, Szulta J, de Almeida ME, et al. Usefulness of PCR method for detection of Leishmania in Poland. Pol J Microbio 2009; 58: 219-22.

13. Myjak P, Szostakowska B, Lass A, et al. Diagnostyka leiszmaniozy z uwzględnieniem genotypowania. Diagnosta Lab 2012; 10: 6-10.

14. Gradoni L. Epidemiological surveillance of leishmaniasis in the European Union: operational and research challenges. Euro Surveill 2013; 18: 20539.

15. Kotłowski A. Cutaneous leishmaniasis in the light of personal observations with regard to its diagnosis and treatment in tropical countries. Wiad Parazytol 1988; 34: 509-14.

16. Lejman K. Przypadek leishmaniozy skórnej. Przegl Lek 1946; 2: 141-2.

17. Powałowska J. Case of multifocal cutaneous leishmaniosis. Przegl Epidemiol 1978; 32: 261-4.

18. Dziubek Z, Horban A, Zarnowska H, et al. Cutaneous leishmaniasis among the cases of the Institute of Infectious and Parasitic Diseases, Medical Academy, in Warsaw. Wiad Parazytol 1988; 34: 663-4.

19. Zając-Marczewska M. Przypadek leiszmaniozy skórnej. XI Zjazd Polskiego Towarzystwa Epidemiologów i Lekarzy Chorób Zakaźnych, Puławy1988.

20.Skoryna-Karcz B, Chojecka-Adamska A, Adamski Z, Czepczynski R. The case of cutaneous leishmaniosis - diagnostic difficulties. Przegl Dermatol 1994; 81: 544-7.

21. Skoryna-Karcz B. Evaluation of the epidemiological and clinical picture in diagnosis of cutaneous leishmaniasis. Postep Dermatol Alergol 1998; 15: 267-91.

22. Skoryna-Karcz B. Difficulties in diagnosis of cutaneous leishmaniasis cases. Probl Hig 2001; 73: 111-4.

23. Wojas-Pelc A, Brzeski M, Jaworek AK, et al. Leiszmanioza skórna - analiza przypadku klinicznego. XXVIII Zjazd Polskiego Towarzystwa Dermatologicznego, Bydgoszcz, 1-5 wrzesień 2004. Przegl Dermatol 2004; 91 (special issue): 41-2.

24. Paul M, Stefaniak J, Wasniowski A. Tropical skin diseases imported by travellers returning from equatorial Africa or Asia. Postep Dermatol Alergol 2007; 24: 16-25.

25. Pilarz $七$, Sikora A, Gębska E. Cutaneous leishmaniasis in Poland. Studium Vilnense A 2009; 6: 148-51.

26. Czepiel J, Biesiada G, Leśniak MR, et al. Cutaneous leishmaniasis in a patient returning from Morocco. Przegl Dermatol 2010; 97: 260-3.

27. Berkan E. Choroby tropikalne leczone w WSS im. W. Biegańskiego w Łodzi: leiszmanioza. Konferencja "Szczepienia ochronne dziś i jutro - medycyna podróży”, tódź 2012.

28. Woźnica E, Ramos Ttito AP, Reich A. Leiszmanioza skórna. Forum Młodych Polskiego Towarzystwa Dermatologicznego XXVI Sympozjum Sekcji Alergologicznej Polskiego Towarzystwa Dermatologicznego. Przegl Dermatol 2014; 101: 359.

29. Olszański R, Siermontowski P, Juszczak D, et al. A case of cutaneous leishmaniasis treated with hyperbaric oxygen therapy. Pol Hyperbaric Res 2016; 57: 39-41.

30. Stefaniak J. Neglected tropical diseases u pacjentów leczonych w Ośrodku Poznańskim w latach 2000-2017. Jubileuszowa Konferencja Naukowo-Szkoleniowa "Zagadnienia wielodyscyplinarne medycyny podróży. Choroby tropikalne i pasożytnicze a zdrowie międzynarodowe". 55 lat Katedry i Kliniki Chorób Tropikalnych i Pasożytniczych Uniwersytetu Medycznego im. Karola Marcinkowskiego w Poznaniu, Poznań 2017.
31. de Wild M, Wiersma FH, Wolfs TF, van Hasselt PM. Cutaneous leishmaniasis in a Syrian refugee. Ned Tijdschr Geneeskd 2016; 160: D429.

32. Bradshaw S, Litvinov IV. Dermal leishmaniasis in a 25-yearold Syrian refugee. CMAJ 2017; 189: E1397.

33. Wollina U, Koch A, Guarneri C, et al. Cutaneous leishmaniasis - a case series from Dresden. Open Access Maced J Med Sci 2018; 6: 89-92.

34. Ready PD. Leishmaniasis emergence in Europe. Eurosurveillance 2010; 15: 29-39.

35. Poeppl W, Obwaller AG, Weiler M, et al. Emergence of sandflies (Phlebotominae) in Austria, a Central European country. Parasitol Res 2013; 112: 4231-7.

36. Wall EC, Watson J, Armstrong M, et al. Epidemiology of imported cutaneous leishmaniasis at the Hospital for Tropical Diseases, London, United Kingdom: use of polymerase chain reaction to identify the species. Am J Trop Med Hyg 2012; 86: 115-8.

37. Bart A, van Thiel PP, de Vries HJ, et al. Imported leishmaniasis in the Netherlands from 2005 to 2012: epidemiology, diagnostic techniques and sequence-based species typing from 195 patients. Euro Surveill 2013; 18: 20544.

38. Poeppl W, Oeser C, Grabmeier-Pfistershammer K, et al. Clinical findings and management of imported cutaneous leishmaniasis: report of 14 cases from Austria. Travel Med Infect Dis 2013; 11: 90-4.

39. Patel TA, Scadding GK, Phillips DE, Lockwood DN. Case report: old world mucosal leishmaniasis: report of five imported cases to the hospital for tropical diseases, London, United Kingdom. Am J Trop Med Hyg 2017; 97: 1116-9.

40.Lawn SD, Whetham J, Chiodini PL, et al. New world mucosal and cutaneous leishmaniasis: an emerging health problem among British travellers. QJM 2004; 97: 781-8.

41. ITB World Travel Trends Report 2016/17. Messe Berlin GmbH, Berlin 2016.

42. Polish Tourism 2016/17 from the perspective of Polish Tour Operators Association. Polish Tour Operators Association, Warsaw 2017

43. Report "Foreign vacation of Poles 2017". Polish Chamber of Tourism, Warsaw 2017.

44.Jaremin B. Criteria and problems related to the diagnosis of malaria, amebiasis and leishmaniasis as occupational disease in Polish citizens. Przegl Epidemiol 1998; 52: 321-8.

45. Roberts T, Barratt J, Sandaradura I, et al. Molecular epidemiology of imported cases of leishmaniasis in Australia from 2008 to 2014. PLoS One 2015; 10: e0119212.

46. Kuna A, Gajewski M, Stańczak J. Evaluation of knowledge and use of the malaria prevention measures among the patients of the Department of Tropical and Parasitic Diseases University Center of Maritime and Tropical Medicine, Gdynia, based on a questionnaire performed in the years 2012-2013. Przegl Epidemiol 2017; 71: 33-44.

47. van Thiel PP, Leenstra T, de Vries HJ, et al. Cutaneous leishmaniasis (Leishmania major infection) in Dutch troops deployed in northern Afghanistan: epidemiology, clinical aspects, and treatment. Am J Trop Med Hyg 2010; 83: 1295-300.

48. Korzeniewski K, Olszański R. Leishmaniasis among soldiers of stabilization forces in Iraq. Review article. Int Marit Health 2004; 55: 155-63.

49. Korzeniewski K. Epidemiology of illnesses and injuries in specific climatic and sanitary conditions on the example of troops deployed to military operations. (Part one). Int Rev Armed Forces Med Serv 2013; 86: 43-57. 
50. Bailey MS. Cutaneous leishmaniasis in British troops following jungle training in Belize. Travel Med Infect Dis 2011; 9: 253-4.

51. van Thiel PP, Zeegelaar JE, van Gool T, et al. Cutaneous leishmaniasis in three Dutch military cohorts following jungle training in Belize. Travel Med Infect Dis 2011; 9: 153-60.

52. Herwaldt BL. Leishmaniasis. Lancet 1999; 354: 1191-9.

53. Mulić R, Custović A, Ropac D, et al. Occurence of visceral and cutaneous leishmaniasis in Croatia. Mil Med 2009; 174: 206-11.

54. Campino L, Maia C. Epidemiology of leishmaniases in Portugal. Acta Med Port 2010; 23: 859-64.

55. Ntais P, Sifaki-Pistola D, Christodoulou V, et al. Leishmaniases in Greece. Am J Trop Med Hyg 2013; 89: 906-15.

56. Arce A, Estirado A, Ordobas M, et al. Re-emergence of leishmaniasis in Spain: community outbreak in Madrid, Spain, 2009 to 2012. Euro Surveill 2013; 18: 20546.

57. Ehehalt U, Schunk M, Jensenius $M$, et al. Leishmaniasis acquired by travellers to endemic regions in Europe: a EuroTravNet multi-centre study. Travel Med Infect Dis 2014; 12: 167-72.

58. Koliou MG, Antoniou Y, Antoniou M, et al. A cluster of four cases of cutaneous leishmaniasis by Leishmania donovani in Cyprus: a case series. J Med Case Rep 2014; 8: 354.

59. Giavedoni P, Iranzo P, Fuertes I, et al. Cutaneous leishmaniasis: 20 years' experience in a Spanish tertiary care hospital. Actas Dermosifiliogr 2015; 106: 310-6.

60. Medenica S, Jovanović S, Dožić I, et al. Epidemiological surveillance of leishmaniasis in Montenegro, 1992-2013. Srp Arh Celok Lek 2015; 143: 707-11.

61. Ponrovsky EN, Strelkova MV, Zavoikin VD, et al. The epidemiological situation of leishmaniasis in the Russian Federation: the first valid cases of local transmission. Med Parazitol (Mosk) 2015; 3: 3-7.

62. Roth-Damas P, Sempere-Manuel M, Mialaret-Lahiguera A, et al. Community outbreak of cutaneous leishmaniasis in La Ribera region of Valencia, Spain: Public Health measures. Enferm Infecc Microbiol Clin 2017; 35: 338-43.

63. Marcoval J, Penín RM. Evolution of cutaneous leishmaniasis in the last 30 years in a tertiary hospital of the European Mediterranean coast. Int I Dermatol 2017; 56: 750-3.

64.Gaspari V, Ortalli M, Foschini MP, et al. New evidence of cutaneous leishmaniasis in north-eastern Italy. J Eur Acad Dermatol Venereol 2017; 31: 1534-40.

65. Rainova I, Harizanov R, Kaftandjiev I, et al. Human parasitic diseases in Bulgaria 2013-2014. Balkan Med J 2018; 35: 61-7.

66. Ahluwalia S, Lawn SD, Kanagalingam J, et al. Mucocutaneous leishmaniasis: an imported infection among travellers to central and South America. BMJ 2004; 329: 842-4.

67. Moreira OC, Yadon ZE, Cupolillo E. The applicability of realtime PCR in the diagnostic of cutaneous leishmaniasis and parasite quantification for clinical management: current status and perspectives. Acta Trop 2018; 184: 29-37.

68. Sagi O, Berkowitz A, Codish S, et al. Sensitive molecular diagnostics for cutaneous leishmaniasis. Open Forum Infect Dis 2017; 4: ofx037.

69. Tomasini C, Moneghini L, Barbui AM. Chronic amastigotenegative cutaneous leishmaniasis: a clinical, histopathologic and molecular study of 27 cases with emphasis on atypical and pseudolymphomatous presentations. J Cutan Pathol 2017; 44: 530-7.

70.Blum J, Buffet P, Visser L, et al. LeishMan recommendations for treatment of cutaneous and mucosal leishmaniasis in travelers, 2014. J Travel Med 2014; 21: 116-29.
71. Aronson N, Herwaldt BL, Libman M, et al. Diagnosis and Treatment of Leishmaniasis: Clinical Practice Guidelines by the Infectious Diseases Society of America (IDSA) and the American Society of Tropical Medicine and Hygiene (ASTMH). Clin Infect Dis 2016; 63: e202-64.

72. Gołąb E, Buczak-Stec E, Myjak P. Laboratory diagnostics of parasitic diseases in Poland and its costs. J Health Policy Insurance Manag - Polityka Zdrowotna 2013; 3: 69-78.

73. Availability and financing of laboratory diagnostics: postaudit report. Supreme Audit Office of Poland, Warsaw 2017.

74. Kurnatowski P, Moroz J. Otolaryngological manifestations of leishmaniosis. Otolaryngol Pol 2016; 70: 2-6. 